\title{
The Relationship of Time Management and Academic Procrastination: A Case of University Students
}

\author{
Ayşe Nihan ARIBAŞ*
}

\begin{abstract}
This research was conducted descriptively to determine the relationships between time management and academic procrastination. The sample of the study consists of 425 people. The data were analyzed using the snowball sampling method and Google survey; The Demographic Information Form was collected using the Time Management Scale and the Academic Procrastination Scale. Independent Sample T-Test, ANOVA Test, and Correlation Test were used to evaluate the data. According to the correlation analysis results, a moderate negative correlation was found between time management and academic procrastination. As the academic procrastination levels of students increase, their time management success decreases. The comparisons made determined that the variables of age, mother's approach, father's approach, voluntary coming to the department, family relationships, and friendship relations affect the time management scale scores. Besides, it was determined that the variables of gender, mother's approach, father's approach, age, and family relationships affect the academic procrastination scale scores. As a result, it was determined that demographic variables affect the scores of time management and academic procrastination scales.
\end{abstract}

Keywords: Time, time management, academic procrastination

\section{Zaman Yönetimi ve Akademik Erteleme İlişkisi: Üniversite Öğrencileri Üzerine Bir Araştırma}

ÖZ

$\mathrm{Bu}$ araştırma, zaman yönetimi ile akademik erteleme arasındaki ilişkileri belirlemek amacıyla tanımlayıcı olarak yapılmıştır. Araştırmanın örneklemi 425 kişiden oluşmaktadır. Veriler, kartopu örneklem yöntemiyle ve Google anket kullanılarak; Demografik Bilgi Formu, Zaman Yönetimi Ölçeği ve Akademik Erteleme Ölçeği kullanılarak toplanmıştır. Verilerin değerlendirilmesinde Bağımsız Örneklem T Testi, ANOVA Testi ve Korelasyon testi kullanılmıștır. Yapılan Korelasyon analizi sonuçlarına göre; zaman yönetimi ve akademik erteleme arasında negatif yönlü orta düzeyde bir ilişki saptanmıştır. Öğrencilerin akademik erteleme düzeyleri arttıkça, zamanı yönetme başarıları azalmaktadır. Yapılan karşılaştırmalarda yaş, anne yaklaşımı, baba yaklaşımı, bölüme isteyerek gelme, aile içi ilişkiler ve arkadaşlık ilişkileri değişkenlerinin zaman yönetimi ölçek puanlarını etkilediği belirlenmiștir. Ayrıca cinsiyet, anne yaklaşımı, baba yaklașımı, yaş ve aile içi ilişkiler değișkenlerinin akademik erteleme ölçek puanlarını etkilediği saptanmıştır. Sonuç olarak demografik değişkenlerin, zaman yönetimi ve akademik erteleme ölçek puanlarını etkilediği belirlenmiștir.

Anahtar Kelimeler: Zaman, zaman yönetimi, akademik erteleme

\section{Introduction}

Time Management is a controlled practice process or a specific activity over time for the purpose of performing specified tasks or actions. In short, it is the ability to optimally organize, plan and use time for specific tasks (Dimitrova \& Ali-Mncheva, 2018). Students who have their own daily routine and lifestyle, which are necessary to balance academics and extracurricular activities, often live a very busy and stressful life as they attend classes, complete homework and study for exams. Also, the need to create time to do everything at once can be difficult and overwhelming, so this is where effective time management skills need to come to life. Time management is a skill that students must learn, allowing students to design plans ahead of time and prioritize upcoming assignments and activities. Time management allows students to organize and focus better on daily life, with more control over their daily lives. In order for students to have good time management skills, they need to change some harmful habits such as academic procrastination because completing academic assignments on time and not procrastinating increase success. If students are motivated and disciplined, their time management skills will improve over time with practice (Cyril, 2015, s. 39). Time Management is an indispensable output of life, especially the education of university students, who are the employees of the future. Students should be given time management skills. Time management skills are considered very important for students to improve

* Öğr. Gör. Dr., Aksaray Üniversitesi, nihan_dinc85@hotmail.com

Makalenin Gönderim Tarihi: 05.04.2021; Makalenin Kabul Tarihi: 10.06.2021 
themselves by reflecting on their education life. Because an individual who can manage his time effectively is superior to others in many ways. Managing time provides individuals with various advantages in many ways. These advantages start with the education life and include the continuation of education life and working life, which is a kind of output.

Procrastination is expressed as a personality trait based on procrastination, a behavioral tendency, or an unreasonable delay (Şirin, 2011). The life of a modern person consists of tasks that must be delivered at certain date intervals. In this case, the individual can plan the effort and time to spend and the resources to be used, but when faced with situations such as the multitude of tasks and excessive workload, he or she may feel the need and desire to postpone the fulfillment of some tasks. Postponement arises from the fact that these tasks are postponed (Saplavska \&Jerkunkova, 2018). Academic procrastination is a problem that needs to be solved especially for university students and can be overcome by learning how to use time effectively. Students who do not procrastinate academically can manage their time effectively and have high academic success because they fulfill their responsibilities on time. In this study, it is aimed to examine the relationship between students' time management skills and academic procrastination. In this context, the data obtained from 425 students studying at a state university will be analyzed using statistical techniques and the relationships between these two concepts will be tried to be revealed.

\section{Conceptual Framework}

\subsection{Time Management}

Time management is a universal phenomenon. Time management is a process that includes the determination of needs and prioritization of tasks. Many people think that time cannot be controlled by itself. Time is not a material thing that can be efficiently executed rather than used by human nature's flow (Khan et al., 2015, s. 250). In real terms, time management means the process of controlling time, which is practically impossible. Based on this definition, the possible situation is self-management that aims to accomplish more than one job in a limited time (Odumeru, 2013). Time management emerges as a concept that everyone needs, depending on the rapid flow of life today. Especially if students know how to use their time effectively, it will provide them with many advantages in their education life and potential professional life. All activities are determined by the student's ability to achieve the set goals without anxiety, stress, or sense of fulfilling the tasks, and generally, the student is not aware of the correct management of time (Ferrero \& Ugidos, 2018: 2). Students should also continue their studies, prepare for academic requirements and exams, and participate in extracurricular activities other than personal activities. Students need to understand time management and the importance of gaining this skill. Moreover, it also helps develop a healthy and versatile personality in a student who has mastered this skill (Nayak, 2018, s. 2000). With time management, individuals will be more efficient in completing their tasks and goals, setting priorities and tasks, and maintaining a balance of flexibility and control over time. Time is simply a resource that cannot be modified, cannot be retrieved when used, and is used entirely at the owner's discretion. Nobody knows the flow of time, but everyone decides how to use it. Time management is self-management with a future-oriented concentration in determining what to do, focusing on how to do activities more efficiently and when the time is right for specific activities (Peng \& Kamil, 2017). It is crucial to make long-term and short-term planning in time management. According to Razali et al. (2017), short-term planning encompasses various elements that require short-term planning during the day or week. Time attitudes are inherently more frugal. Long-term planning competence takes a longer view of daily work by tracking actual dates and setting goals with procrastination. These time management behaviors have a precise and straightforward meaning for effective performance (Razali et al., 2017). Researchers believe that time is the primary resource in human life and should be used better because time cannot be balanced with a price because management and time are complementary concepts. After all, planning, organization, guidance, and control underlie our time's effective management by using management process elements. This helps us use our time correctly and achieve our set goals with less time, effort, and cost. (Hila et al., 2017, s. 141). There are various time management approaches that minimize procrastination and interruptions and increase discipline, especially in research activities. These 
approaches are; monitoring, goal setting, prioritization, planning, authorization and analysis of time spent (Chase et al., 2013, s. 60).

\subsection{Academic Procrastination}

Procrastination has been one of the most studied social sciences topics due to its adverse effects on the general population and the student population. A general tendency to postpone academic duties is defined as academic procrastinationin the academic environment.

Although procrastination is a common phenomenon and a negative feature, it is difficult to define it as acceptable in the literature. When the definitions of procrastination are compared, it is seen that procrastination consists of actions and behaviors that have a negative effect on the productivity of the individual (Balk1s \& Duru, 2009, s.19). Procrastination behavior is examined in three ways as arousal delay, avoidance delay, and decision-making procrastination. Arousal procrastination is when an individual exhibits procrastination behavior for entertainment and tension. In avoidance procrastination, the individual exhibits procrastination behavior for self-protection due to fear. In the deferral of decision making, the individual exhibits procrastination behavior in order to delay his decisions (Eltayeb, 2021, s. 19).

Academic procrastination, which is used in the same sense as student procrastination, is the postponement of tasks and activities related to learning and study for a limited period of time (Steel \& Klingsieck, 2016, s. 37). Academic procrastination, defined as academic procrastinationby Rothblum et al., (1986), was defined as the experienced anxiety about the tendency to postpone academic tasks. Academic procrastinationis a common problem among students, and students have to deal with academic procrastinationin almost every stage of education due to its negative consequences, such as academic failure and lower quality welfare (Balk1s \& Duru, 2017, s. 108). Academic procrastination behavior, which we can define as a subtype of procrastination behavior, generally includes academic tasks and can be defined as procrastinationing academic work for some reasons (Akbay \& Gizir, 2010, s. 61). One of those defining academic procrastination is the Chu. According to $\mathrm{Chu}$, active academic procrastination is an adaptive learning method in which people temporarily escape from academic tasks to reduce stress or obtain more resources. The opposite is passive procrastination. In passive procrastination, the individual's intention is not to postpone the academic assignment, but still, the academic task is procrastinationed (Fuqiang \& Qian, 2018, s. 4).

It is observed that university students exhibit widespread academic procrastination since they have more duties and responsibilities such as preparing for homework, studying, and preparing for exams. When the relevant literature is examined, many studies have been found on university students' academic procrastination. The first stage of these studies consists of studies examining academic procrastinationlevels (Abu \& Saral, 2016).

Ojo (2019) indicated that there are many reasons behind students' academic procrastination behavior. These can be classified as forgetting, not being clear about the desired task, not being allowed in deadlines, presence of distracting factors, fear of failure, overloading and resistance.

\subsection{The Relationship Between Time Management and Academic Procrastination}

Some of the findings obtained from various studies are similar to the research, and some give different results from the research. Results; The mean scores of the time management sub-dimension of the students did not differ significantly according to the operational status, class, program, parents' educational status (Gayef et al., 2017), female students plan their time management better than male students and (Tektaş \& Tektaş, 2010), points out that there is a relationship between students 'age and time management skills, but there is no difference in time management in terms of gender, there is a weak relationship between students' time management and their academic achievement, and there is no difference in time management in terms of gender (Razali et al., 2017).

According to Çelik and Odacı (2015), as a result of the research, it was revealed that academic procrastinationbehavior differs according to gender, grade level, and academic achievement, and it did not differ significantly according to the faculty attended. According to Aydın and Koçak (2016); It has been 
revealed that there is a negative, moderate, significant relationship between students' time management skills and academic procrastination behaviors.

\section{Method}

\subsection{Problem, Type and Purpose of the Research}

The problem of the research is to examine the relationship between students' time management and academic procrastination. The sub-problem of the research is that to examine whether there is a statistical difference in terms of the time management and academic procrastination statuses depend on demographic variables (age, gender, class, program, graduated high school, coming to the department voluntarily, longest place of residence, family type, family relations, friend relations, mother and father attitude).

In the descriptive study, the relational screening model, which is used to determine the relationship between two variables, was used. In this study, it is aimed to examine the relationship between time management and academic procrastination. For this purpose, the following hypotheses were formed;

H0: There is a relationship between students' academic procrastination and time management.

H1: There is no relationship between students' academic procrastination and time management.

H2: Age reveals statistically significant differences in the perception of time management.

H3: Gender reveals statistically significant differences in the perception of time management.

H4: Voluntary to come to the department reveals statistically significant differences in the perception of time management.

H5: Family relations reveals statistically significant differences in the perception of time management

H6: Friendship relations reveals statistically significant differences in the perception of time management

H7: The mother father approach reveals statistically significant differences in the perception of time management.

H8: The father approach reveals statistically significant differences in the perception of time management.

H9: Age reveals statistically significant differences in the perception of academic procrastination levels. H10: Gender reveals statistically significant differences in the perception of academic procrastination levels.

H11: The mother approach reveals statistically significant differences in the perception of academic procrastination.

H12: The father approach reveals statistically significant differences in the perception of academic procrastination.

\subsection{The Universe and Sample of the Research}

This research was conducted as a descriptive study to determine the relationship between time management and academic procrastination, and a relational survey model that determines the relationships between two or more variables was used in the study.

This research was carried out as a descriptive research to determine the relationship between time management and academic procrastination, and the relational survey model, which determines the relationships between two or more variables, was used in the research. The universe of the research, consists of students who studied and graduated from a state university between the dates of the research. The sample of the study consists of 425 people who agreed to participate in the study. Persons who voluntarily participated in the research between February and April 2021, when data were collected and completed the questionnaires and scales, were included.

\subsection{Data Collection, Data Collection Tools and Ethical Aspect of the Research}

Data; It was collected by online questionnaire method and by using Time Management Scale and Academic ProcrastinationBehavior Scale. 
Time Management Scale (FIS): It is a 16-item scale with three sub-dimensions developed by Britton and Tesser in 1991, and whose validity and Alay and Koçak made reliable in 2002. Each item was scored on a 5-point scale, and a five-point scale consisting of options such as "always, often, sometimes, rarely and never" was used. In the scoring, 5 was given to the last answer, while 1 was given to the answer on the other side (Alay\&Koçak, 2002; as cited in Alay \&Koçak, 2003: Altuntaş \& Kayıhan, 2013).

Time Management Scale Sub-Dimensions:

Time planning subscale: The time planning subscale includes long and short-term planning, and there are 16 questions on the scale, one of which (item 16) is reverse-coded. It is stated that students who get higher scores on this scale use their time better.

Time attitudes subscale: The time attitudes subscale consists of 7 items, 4 of which are straight and 3 (items 2, 6, and 7) with reverse expressions, which include items about what the person is doing about time management. It was stated that students who got high scores from this subscale manage their time well.

Time savers subscale: The time-savers subscale, on the other hand, consists of 4 items related to activities that spend $\mathrm{n}$ time negatively, all of which contain reverse expressions. The sum of the scores obtained from these three sections gives the result of ADC.

The maximum score obtained from FIC is 135, and the minimum score is 27 (Alay et al. 2002; Alay et al., 2003; Başak et al., As cited in 2008: Altuntaş \& Kaylhan, 2013).

Academic Procrastination Scale (APS): Developed by Çakıc1 (2003), the Academic ProcrastinationScale consists of 19 items that include tasks such as studying, preparing for exams, and preparing projects in students' education life. 12 of these items are reverse-coded, and 7 of them are $(1,4,7,9,11,13,17)$ is positive. This scale is graded in Likert type. The expressions in the scale are "not reflecting me at all," "slightly reflecting me," "slightly reflecting me," "mostly reflecting me," "fully reflecting me"; Those who say "it does not reflect me at all" are scored as 1, and those who say "it reflects me completely" are scored as 5 points for an expression that includes academic procrastination. The highest score obtained from the scale is 95 , and the lowest score is 19 . High scores from the scale indicate that students have high procrastinationbehavior in academic subjects (Çakıc1, 2003).

Written permission was obtained from the Aksaray University Human Research Ethics Committee to conduct the study (Date: 22/02/2021 and number: 2021 / 01-115).

\subsection{Data Analysis}

Statistical analysis of the data was carried out with the SPSS 24 package program. T-Test and Anova tests were used to test the analyzes because the number of samples was more than 30 and the data were suitable for normal distribution (Tabachnick \& Fidel, 2013). On the other hand, Correlation analysis was used to determine the relationship between scale scores. The Time Management Scale's reliability is .825, and the reliability of the Academic Procrastination Scale is .828.

\section{Findings}

Table 1. Demographic Characteristics of the Participants $(n=425)$

\begin{tabular}{cccc} 
Demographic Characteristics & & Number & Percent (\%) \\
\hline \multirow{2}{*}{ Age } & $18-20$ age & 228 & $\% 53,6$ \\
& $21-43$ age & 197 & $\% 46,4$ \\
\hline \multirow{2}{*}{ Gender } & Female & 331 & $\% 77,9$ \\
& Male & 94 & $\% 22,1$ \\
\hline \multirow{2}{*}{ Program } & Associate degree & 125 & $\% 29,4$ \\
& Undergraduate & 300 & $\% 70,6$ \\
\hline \multirow{2}{*}{ Class } & 1.class & 186 & $\% 43,8$ \\
& 2.class & 118 & $\% 27,8$ \\
& 3.class & 54 & $\% 12,7$ \\
& 4.class & 50 & $\% 11,8$ \\
& Graduate & 17 & $\% 04,0$ \\
\hline Voluntary coming to the & Yes & 324 & $\% 76,2$ \\
department & No & 101 & $\% 23,8$ \\
\hline
\end{tabular}




\begin{tabular}{cccc}
\hline & Basic high school & 42 & $\% 9,9$ \\
& Anatolian High School & 210 & $\% 49,4$ \\
Graduated high school & Health voc. high school & 55 & $\% 12,9$ \\
& Vocational High School / & 118 & $\% 27,8$ \\
& Imam Hatip High School & 87 & $\% 20,5$ \\
& Village/town & 99 & $\% 23,3$ \\
& District & 239 & $\% 56,2$ \\
\hline \multirow{2}{*}{ Longest living place } & Province & 332 & $\% 78,1$ \\
& Nuclear family & 79 & $\% 18,6$ \\
& Extended family & 14 & $\% 3,3$ \\
\hline \multirow{2}{*}{ Family type } & Broken family & 281 & $\% 66,1$ \\
& Good & 134 & $\% 31,5$ \\
\multirow{2}{*}{ Family relationships } & Middle & 10 & $\% 2,4$ \\
& Bad & 336 & $\% 79,1$ \\
& Good & 82 & $\% 19,3$ \\
\multirow{2}{*}{ Friend relationships } & Middle & 7 & $\% 1,6$ \\
\hline \multirow{2}{*}{ Mother approach } & Bad & 333 & $\% 78,4$ \\
& Democratic & 92 & $\% 21,6$ \\
\hline \multirow{2}{*}{ Father approach } & Not democratic & 318 & $\% 074,8$ \\
& Democratic & 107 & $\% 25,2$ \\
\hline
\end{tabular}

$91.8 \%$ of the participants are between the ages of 18 and $24,77.9 \%$ are women. Besides, $49.4 \%$ of the participants are Anatolian high school graduates, $70.6 \%$ are studying in undergraduate/graduate programs, and $76.2 \%$ have voluntarily attended the department they study. $79.1 \%$ of the participants stated that they had good friendship relations and $66.1 \%$ stated that their family relations were good.

Table 2. Time Management and Academic Procrastination Scale Scores of the Participants

\begin{tabular}{ccc} 
Scales and Subscales & Mean \pm SS & Min-Max \\
\hline Time Management Scale & $71,01 \pm 12,69$ & $35-113$ \\
Time Planning Sub-Scale & $41,18 \pm 10,26$ & $17-75$ \\
Time Attitudes Subscale & $19,17 \pm 3,64$ & $8-28$ \\
Time Spenders Subscale & $10,65 \pm 2,99$ & $4-20$ \\
Academic Procrastination Scale & $62,71 \pm 10,94$ & $28-87$ \\
\hline
\end{tabular}

The time management total score average of the participants is $71.08 \pm 12.69$. The total mean score of women's time management is $70.64 \pm 12.87$, while the mean total score of men's time management is $72.35 \pm 11.99$. According to these findings; It was concluded that men are better at time management than women. The mean scores of the time management subscales, respectively; Time planning sub-dimension was $41.18 \pm 10.26$, time attitudes sub-dimension was $19.17 \pm 3.64$, and time wasting sub-dimension was $10.65 \pm 2.99$. The mean scores of the time management subscales, respectively; Time planning subdimension was $71.01 \pm 12.69$, time attitudes sub-dimension was $19.17 \pm 3.64$, and time wasting subdimension was $10.65 \pm 2.99$. According to these findings, it was concluded that students use time well, manage time moderately well and have moderate time wastage.

The academic procrastination total score average is $62.71 \pm 10.94$. The total mean score of academic procrastination of women is $63.69 \pm 11.03$ and the mean of total score of academic procrastination of men is $59.25 \pm 9.91$. According to this finding, the academic procrastination of women is higher than that of men. 
Table 3. Relationship Between the Mean Scores of the Scales Scales and Sub-scales

\begin{tabular}{ccccccc} 
Scales and Sub-scales & & 1 & 2 & 3 & 4 & 5 \\
\hline \multirow{2}{*}{ 1. Time Management Scale } & $\mathrm{r}$ & 1 & & & & \\
& $\mathrm{p}$ & - & & & & \\
& $\mathrm{r}$ & $0,913^{* *}$ & 1 & & & \\
2. Time Planning Sub-Scale & $\mathrm{p}$ & 0,000 & - & & \\
& $\mathrm{r}$ & $0,636^{* *}$ & $0,385^{* *}$ & 1 & & \\
3. Time Attitudes Sub-Scale & $\mathrm{p}$ & 0,000 & 0,000 & - & & \\
& $\mathrm{r}$ & $0,344^{* *}$ & 0,063 & $0,233^{* *}$ & 1 & \\
4. Time Spenders Subscale & $\mathrm{p}$ & 0,000 & 0,000 & 0,000 & - & \\
& $\mathrm{r}$ & $-0,597^{* *}$ & $-0,491^{* *}$ & $-0,386^{* *}$ & $-0,419^{* *}$ & 1 \\
5. Academic Procrastination Scale & $\mathrm{p}$ & 0,000 & 0,000 & 0,000 & 0,000 & - \\
\hline
\end{tabular}

When the total time management scores of the students are examined, it is seen that they are above the average in time management. As a result of the correlation analysis (Table 3), there is a moderate negative correlation between time management and academic procrastination $(\mathrm{p}<0.05)$. Also, there is a negative correlation between academic procrastination and the time management subscale, time planning subscale, time attitudes subscale, and time savers subscale $(\mathrm{p}<0.05)$. According to this finding, as the time management inventory score increases, the academic procrastination score decreases, and as the time management score decreases, the academic procrastination score increases.

Table 4. Factors Affecting the Time Management and Academic Procrastination Scale Score Averages of the Participants

\begin{tabular}{|c|c|c|c|c|c|}
\hline \multirow[b]{2}{*}{ Variables } & & \multicolumn{2}{|c|}{ Time Management } & \multicolumn{2}{|c|}{ Academic Delay } \\
\hline & & $\mathbf{x}$ & ss & $\mathbf{X}$ & ss \\
\hline \multirow[t]{5}{*}{ Age } & 18-24 age & 71,44 & 12,81 & 62,54 & 11,02 \\
\hline & 25-31 age & 67,39 & 10,13 & 61,89 & 8,54 \\
\hline & $32-43$ age & 61,71 & 10,27 & 75,28 & 7,49 \\
\hline & $\mathrm{X}^{2^{*}}$ & 6,924 & & 10,030 & \\
\hline & $\mathrm{p}$ & 0,031 & & 0,007 & \\
\hline \multirow[t]{4}{*}{ Gender } & Female & 70,64 & 12,87 & 63,69 & 11,03 \\
\hline & Male & 72,35 & 11,99 & 59,25 & 9,91 \\
\hline & $\mathrm{Z}^{*}$ & $-1,517$ & & $-4,146$ & \\
\hline & $\mathrm{P}$ & 0,129 & & 0,000 & \\
\hline \multirow{4}{*}{ Program } & Associate degree & 70,91 & & 63,57 & 10,87 \\
\hline & Undergraduate / Above & 71,06 & & 62,35 & 10,96 \\
\hline & $\mathrm{Z}^{*}$ & $-0,273$ & & $-0,878$ & \\
\hline & $\mathrm{P}$ & 0,785 & & 0,380 & \\
\hline \multirow[t]{7}{*}{ Class } & 1.class & 70,89 & 12,53 & 63,43 & 10,89 \\
\hline & 2.class & 71,75 & 12,57 & 62,15 & 11,64 \\
\hline & 3.class & 71,09 & 13,89 & 62,66 & 11,23 \\
\hline & 4.class & 71,62 & 12,23 & 61,16 & 9,41 \\
\hline & Postgraduate & 65,23 & 12,46 & 63,41 & 10,11 \\
\hline & $\mathrm{X}^{2^{*}}$ & 0,703 & & 3,103 & \\
\hline & $\mathrm{p}$ & 0,872 & & 0,376 & \\
\hline \multirow{4}{*}{$\begin{array}{l}\text { Voluntary coming to the } \\
\text { department }\end{array}$} & Yes & 69,98 & 11,86 & 63,23 & 10,87 \\
\hline & No & 74,32 & 14,62 & 61,04 & 11,88 \\
\hline & $\mathrm{Z}^{*}$ & $-2,456$ & & $-1,389$ & \\
\hline & $\mathrm{p}$ & 0,014 & & 0,165 & \\
\hline \multirow[t]{6}{*}{ Graduated high school } & Basic high school & 70,09 & & 63,64 & 10,69 \\
\hline & Anatolian High School & 71,41 & & 62,71 & 10,73 \\
\hline & Health M. High School & 70,10 & & 63,16 & 11,02 \\
\hline & Vocational High School / & 71,06 & & 62,71 & 11,45 \\
\hline & $\begin{array}{l}\text { Imam Hatip High School } \\
\mathrm{X}^{2^{*}}\end{array}$ & 0,651 & & 0,782 & \\
\hline & $\begin{array}{l}A^{2} \\
p\end{array}$ & 0,885 & & 0,854 & \\
\hline \multirow[t]{2}{*}{ Longest living place } & Village / town & 70,71 & 13,05 & 62,41 & 11,31 \\
\hline & District & 70,77 & 12,26 & 64,38 & 10,24 \\
\hline
\end{tabular}




\begin{tabular}{|c|c|c|c|c|c|}
\hline & Province & 71,23 & 12,78 & 62,12 & 11,05 \\
\hline & $\mathrm{X}^{2^{*}}$ & 0,241 & & 2,634 & \\
\hline & $\mathrm{p}$ & 0,887 & & 0,268 & \\
\hline \multirow[t]{5}{*}{ Family Type } & Nuclear family & 71,15 & 12,71 & 62,57 & 11,02 \\
\hline & Extended family & 70,93 & 12,97 & 62,89 & 10,81 \\
\hline & Broken family & 68,35 & 10,89 & 64,85 & 10,05 \\
\hline & $\mathrm{X}^{2^{*}}$ & 0,409 & & 0,138 & \\
\hline & $\mathrm{p}$ & 0,815 & & 0,933 & \\
\hline \multirow[t]{5}{*}{ Family relationships } & Good & 69,60 & 12,57 & 63,59 & 11,16 \\
\hline & Middle & 74,02 & 12,45 & 60,91 & 10,31 \\
\hline & $\mathrm{Bad}$ & 70,50 & 15,18 & 62,20 & 10,84 \\
\hline & $\mathrm{X}^{2^{*}}$ & 12,289 & & 7,843 & \\
\hline & $\mathrm{p}$ & 0,002 & & 0,020 & \\
\hline \multirow[t]{5}{*}{ Friend relationships } & Good & 69,60 & 12,50 & 63,69 & 11,16 \\
\hline & Middle & 74,02 & 12,45 & 60,91 & 10,31 \\
\hline & $\mathrm{Bad}$ & 70,50 & 15,18 & 62,20 & 10,84 \\
\hline & $\mathrm{X}^{2^{*}}$ & 8,759 & & 3,901 & \\
\hline & $\mathrm{p}$ & 0,013 & & 0,142 & \\
\hline \multirow[t]{4}{*}{ Mother approach } & Democratic & 69,83 & 12,25 & 63,56 & 10,66 \\
\hline & Not democratic $Z^{*}$ & 75,31 & 13,35 & 59,63 & 11,42 \\
\hline & $\mathrm{P}$ & $-3,539$ & & $-2,635$ & \\
\hline & & 0,000 & & 0,008 & \\
\hline \multirow[t]{4}{*}{ Father approach } & Democratic & 69,95 & 12,58 & 63,37 & 11,13 \\
\hline & Not democratic $Z^{*}$ & 74,16 & 12,52 & 60,74 & 10,13 \\
\hline & $\mathrm{p}$ & $-3,216$ & & $-2,706$ & \\
\hline & & 0,001 & & 0,007 & \\
\hline
\end{tabular}

When the Time Management scores were examined (Table 4); It was found that the time management scores were not statistically significant according to the variables of age, gender, program, class, high school from which they graduated, the most extended place of residence and family type $(p>0.05)$. It was found that the time management scores were statistically significant according to the variables of mother's approach, father's approach, voluntary coming to the department, family relations, and friendship relations $(\mathrm{p}<0.05)$.

When academic procrastination scores were examined (Table 4), it was found that academic procrastination scores were not statistically significant according to the variables of program, age, family relations voluntary coming to the department, class, high school graduated, most extended place of residence, family type, and friendship relations $(\mathrm{p}>0.05)$. It was found that academic procrastination scores were significant according to the variables of gender, mother approach, father approach $(p<0.05)$.

\section{Result, Discussion and Suggestions}

This research was conducted to examine the relationship between time management and academic procrastination. According to the research results, there is a negative relationship between academic procrastination and time management. Also, according to the findings, as academic procrastination increases, time management decreases and vice versa.

In addition, hypotheses have been developed to reveal whether demographic variables are statistically significant in the context of time management and academic procrastination. According to the result of our study, it is found that; time management scores were statistically significant according to the variables of mother's approach, father's approach, voluntary coming to the department, family relations and friendship relations $(p<0.05)$. Besides, academic procrastination scores were significant according to the variables of gender, mother approach, father approach $(\mathrm{p}<0.05)$. According to the findings, H0, H4, H5, H6, H7, H8, H10, H11 and H12 hypotheses were accepted.

Findings from Chanpisut's (2018) study, unlike our research, show that female students plan their time better than male students. According to the findings obtained from the study of Hafner et al. (2014), who divided the students into two groups as assessment and treatment groups, and thus investigated the relationship between time management and academic procrastination; the students in the control group showed procrastination behavior and the students in the evaluation group did not show a snooze 
behavior. The study on undergraduate students results conducted by Ocak \& Boyraz (2016) and the study of Shih (2017) on adolescents show that there is a negative relationship between time management and academic procrastination, similar to our research. According to the results of the research, examining academic procrastination and the effective use of time, unlike our study, there were statistically significant differences in the academic procrastination behaviors of the students, but no statistically significant difference was found in the results related to the effective use of time (Košíková et al, 2020).

In another study by Ferdus et al (2015), examining the time management behavior among academic procrastinators, it was concluded that the time spent by university students for academic purposes was inversely proportional to the frequency of their procrastination, and that the time not used for academic purposes was positively associated with procrastination.

Among the findings obtained from various studies, there are some similar and different results presented to our study. Similar to our research, there are many studies in which gender reveals statistically significant differences in the perception of academic procrastination (Ghosh \& Roy, 2017; Zarrin et al., 2020; Khan et al. 2014; Özer et al., 2009; Akinsola et al. 2007). In addition, unlike to our research, in the study of Khan et all (2014); it was found that there is are statistically significant differences in the perception of academic procrastination with age. Unlike our research, in the study of Bertsch et al. (2017), gender and age reveal statistically significant differences in the perception of time management, and similar to our research, in the study of Hanpisut (2018) and in the study of Khanam et al. (2018), gender did not reveal statistically significant differences with time management. Again, similar to our research, according to the findings obtained from the study of Gayef et al. (2017), the program does not create a statistically significant difference in the perception of time management.

University education, which is the most important and final stage of education life, is considered very important in our country and in the world, as students can effectively use the gains they have obtained during this education until the end of their lives. It is expected that students who know how to plan their time effectively, who do not have problems in using time effectively and who do not exhibit procrastination behavior will maintain this behavior and be more successful in their business life. This issue is considered important for young people who shape the future of countries to act by solving problems and raising awareness.

This research was limited to the students of the health services vocational school and health sciences faculty of a state university. This study was carried out on students from several different universities, and the results can be compared with this research. In addition, similar studies in other sectors can be repeated in different samples. In the study, an application was made only for students studying in the field of health sciences, and it would be useful to compare applications for different occupational groups. In addition, the concepts discussed in the research can be associated with other issues in the field of organizational behavior. In addition, more comprehensive studies can be conducted examining time management and academic procrastination behavior. It is expected that the results of this research will contribute to other researchers who will work on university students.

\section{References}

Abu, K, N ve Saral, G, D. (2016) "The Reasons Of Academic Procrastination Tendencies Of Education Faculty Students", The Online Journal of New Horizons in Education, 6(1), 165- 169.

Akbay, E, S ve Gizir, A, C. (2011) "Cinsiyete Göre Üniversite Öğrencilerinde Akademik Erteleme Davranışı: Akademik Güdülenme, Akademik Özyeterlik ve Akademik Yükleme Stillerinin Rolü, Mersin Üniversitesi Ë̆itim Fakïltesi Dergisi, 6(1), 60-78.

Akinsola, K, M, Tella, A and Tella, A (2007). Correlates of Academic Procrastination and Mathematics Achievement of University Undergraduate Students. Eurasia Journal of Mathematics, Science \& Technology Education, 3 (4), 364-370.

Alay, S ve Koçak, S. (2002) “Zaman Yönetimi Anketi: Geçerlik ve Güvenirlik”, Hacettepe Üniversitesi Eğitim Fakültesi Dergisi, 22, 9-13.

Alay, S ve Koçak, S. (2003). Üniversite Ögrencilerinin Zaman Yönetimleri İle Akademik Başarıları Arasindaki İlisski. In Theory \& Practice, 35, 326-335. 
Altuntaş, O ve Kayıhan, H. (2013) Üniversite Öğrencilerinin Zaman Yönetimi Farkındalıklarının Incelenmesi, Ergoterapi ve Rehabilitasyon Dergisi, 1 (2), 47-53.

Aydın, S, K ve Koçak, S. (2016) Üniversite Öğrencilerinin Zaman Yönetimi Becerileri İle Akademik Erteleme Düzeylerinin İncelenmesi, Uşak Üniversitesi Ë̆itim Araştırmalar Dergisi, 2 (3), 17-38.

Balkıs, M and Duru, E. (2009). Prevalence Of Academic Procrastination Behavior Among Pre-Service

Teachers, And Its Relatıonship With Demographics And Individual Preferences. Eğitimde Kuram ve Uygulama, Journal Of Theory And Practice In Education, 5 (1), 18-32.

Balk1s, M ve Duru, E. (2017) "Gender Differences in the Relationship between Academic Procrastination, Satisfaction with Academic Life and Academic Performance", Electronic Journal of Research in Educational Psychology, 15(1), 105-125.

Bertsch, A, Ondracek, J, Saeed, M, Stone, C, Erickson, K, Opdahl, K, Fitterer, J, D and Magana, S. (2017). Free Time Management Of University Students In The Usa. GE- International Journal Of Management Research, 5 (8), 63-91.

Britton, B, K And Tesser, A. (1991). Effects Of Time-Management Practices On College Grades. Journal Of Educational Psychology, 83(3), 405-410.

Chase, D, J, Topp, R, Smith, E, C, Cohen, Z, M, Fahrenwald, N, Zerwic, J, J, Benefield, E, L, Anderson, M, C and Conn, S, V (2013). Time Management Strategies for Research Productivity. Western Journal of Nursing Research, 35 (2), 155-176.

Chanpisut, A. (2018). Time Management Capabilities of Undergraduate Students at a Private Thai University. Catalyst, 18, 77-87.

Cyril, V, A. (2014). Time Management And Academic Achievement Of Higher Secondary Students. $\dot{I}-$ Manager's Journal on School Educational Technology, 10 (3), 38-43.

Çakıcı, Ç, D. (2003) "Lise Ve Üniversite Öğrencilerinde Genel Erteleme Ve Akademik Erteleme

Davranışının İncelenmesi”. Yükesek Lisans Teži, Ankara Üniversitesi Eğitim Bilimleri Enstitüsü, Ankara.

Çelik, B, Ç ve Odacı, H. (2015) "Akademik Erteleme Davranışının Bazı Kişsel ve Psikolojik

Değişskenlere Göre Aç1klanması”, Hacettepe Üniversitesi Ĕ̈itim Fakültesi Dergisi, 30(3), 31-47.

Dimitrova, V and Ali-Mancheva, O (2018). Planning And Time Management. International Conference Knowledge-Based Orgamiation, 24 (1), 283-288.

Eltayeb, F. (2021). Mindfulness and Its Relation to Academic Procrastination among University Students. Universal Journal of Educational Research, 9 (5), 917-927.

Ferdus, Z, Kabir, T and Akter, S. (2015). Time Management Behavior among Academic Procrastinators in Bangladesh: A Study on Undergraduate Students of Different Private Universities. Journal of Business and Technology (Dhaka), 10(2), 37-56.

Ferrero, M, A and Ugidos, A. (2018) "Time management: skills to learn and put into practice", Education + Training (C) Emerald Publishing Limited, 1-16.

Fuqiang, Z and Qian, L., (2018) “Academic Stress, Academic Procrastination, And Academic Performance: A Moderated Dual-Mediation Model, RISUS - Journal on Innovation and Sustainability, 9,(2), 38-46.

Gayef, A, Tapan, B ve Sur, H. (2017) "Relationship Between Time Management Skill and Academic Achievement of The Students in Vocational School of Health Services", Hacettepe Sağllk İdaresi Dergisi, $20(2), 247-257$.

Ghosh, R and Roy, S. (2017). Relating Multidimensional Perfectionism And Academic Procrastination Among Indian University Students Is There Any Gender Divide?. Gender in Management: An International Journal, 32(8), 518-534.

Häfner, A, Oberst, V and Stock, A. (2014). Avoiding Procrastination Through Time Management: An Experimental İntervention Study. Educational Studies, 40(3), 352-360.

Hila, A, A, Shobaki, A, M, Naser, A, S. ve Amuna, A, Y.,(2017) "The Reality of the Effectiveness of Time Management from the Perspective of the Employees of the Beauty Clinic of Dentistry", International Journal of Engineering and Information Systems (IJEAIS), 1(6), 137-156.

Khan, J, M, Arif, H, Noor, S, S and Muneer, S. (2014). Academic Procrastination among Male and Female University and College Students. FWU Journal of Social Sciences, 8(2), 65- 70. 
Khan, S, M and Nasrullah, S. (2015) “The Impact of Time Management on the Students' Academic Achievements, Journal of Literature, Languages, and Linguistics An International", Peer-reviewed Journal, 11, 65-71.

Khanam, N, Sahu, T, Rao, V, E, Kar, K, S And Quazi, Z, S. (2017). A Study On University Student's Time Management And Academic Achievement. International Journal Of Community Medicine And Public Health, 4(12), 4761-4765.

Košíková, M, Loumová, V, Koval’ová, J, Vašaničová, P, Bondarenko, M, V. (2020). A Cross-Culture Study of Academic Procrastination and Using Effective Time Management. Periodica Polytechnica Social and Management Sciences, 28 (2), 121-128.

Nayak, G, S. (2018) "Time Management in Nursing -Hour of need", International Journal of Caring Sciences, 11(3), 1-4.

Ocak, G. ve Boyraz, S. (2016) "Examination of the Relation between Academic Procrastination and Time Management Skills of Undergraduate Students in Terms of Some Variables", Journal of Education and Training Studies, 4(5), 76-84.

Odumeru, A, J. (2013). Effective Time Management. Singaporean Journal Of Business Economics, And Management Studies, 2(1), 9-17.

Ojo, A, A. (2019). The Impact Of Procrastination On Students Academic Performance In Secondary Schools. International Journal Of Sociology And Anthropology Research, 5(1), 17-22.

Özer, U, B, Demir, A and Ferrari, R, J. (2009). Exploring Academic Procrastination Among Turkish Students: Possible Gender Differences in Prevalence and Reasons, The Journal of Social Psychology, 149(2), 241-257.

Peng, Z, T ve Kamil, M, B, A. (2017) "Time Management, Procrastination And Priorttzation: A Framework For Service Based Learning Module", e-Academia Journal, (http://journaleacademiauitmt.uitm.edu.my/v2/index.php/home.html), 6(2), 60-70.

Razali, M, A, N, S, Rusiman, S, M, Gan, W, S ve Arbin, N. (2017) “The Impact of Time Management on Students' Academic Achievement”, IOP Conf. Series: Journal of Physics: Conf. Series, 995, 1-7.

Saplavska, J and Jerkunkova, A. (2018). Academic Procrastınation And Anxiety Among Students. Engineerng For Rural Development, 23, 1192-1197.

Shih, S, S. (2017). Factors Related To Taiwanese Adolescents' Academic Procrastination, Time Management, And Perfectionism, The Journal Of Educational Research, 110(4), 415- 424.

Steel, P and Klingsieck, B, K. (2016). Academic Procrastination: Psychological Antecedents Revisited. Australian Psychologist, 51, 36-46.

Şirin, F, Ö. (2011). Academic Procrastination Among Undergraduates Attending School Of Physical Education And Sports: Role Of General Procrastination, Academic Motivation And Academic SelfEfficacy. Educational Research And Reviews, 6(5), 447-455.

Tabachnick, B, G and Fidel, L, S. (2013). Using Multivariate Statistics (Sixth Edition). Boston: Pearson Education, Inc.

Tektaş, M ve Tektaş, N. (2010). "Meslek Yüksekokulu Öğrencilerinin Zaman Yönetimi ve Akademik Başarıları Arasındaki İlişki”, Selçuk Üniversitesi Sosyal Bilimler Enstitüsü Dergisi, 23, 221-229.

Zarrin, A, S, Gracia, E and Paixão, P, M. (2020). Prediction of Academic Procrastination by Fear of Failure and Self-Regulation. Educational Sciences: Theory \& Practice, 20(3), 34-43. 